\title{
The role of intra-articular neuronal CCR2 receptors in knee joint pain associated with experimental osteoarthritis in mice
}

Shingo Ishihara', Alia M. Obeidat', David L. Wokosin², Dongjun Ren³ ${ }^{3}$, Richard J. Miller ${ }^{3}$, Anne-Marie Malfait ${ }^{1}$ and Rachel E. Miller ${ }^{1 *}$ (D)

\begin{abstract}
Background: $\mathrm{C}-\mathrm{C}$ chemokine receptor 2 (CCR2) signaling plays a key role in pain associated with experimental murine osteoarthritis (OA) after destabilization of the medial meniscus (DMM). Here, we aimed to assess if CCR2 expressed by intra-articular sensory neurons contributes to knee hyperalgesia in the early stages of the model.
\end{abstract}

Methods: DMM surgery was performed in the right knee of 10-week-old male wild-type (WT), Ccr2 null, or Ccr2 ${ }^{\text {RFP }}$ C57BL/6 mice. Knee hyperalgesia was measured using a Pressure Application Measurement device. CCR2 receptor antagonist (CCR2RA) was injected systemically (i.p.) or intra-articularly (i.a.) at different times after DMM to test its ability to reverse knee hyperalgesia. In vivo $\mathrm{Ca}^{2+}$ imaging of the dorsal root ganglion (DRG) was performed to assess sensory neuron responses to CCL2 injected into the knee joint cavity. CCL2 protein in the knee was measured by ELISA. C Cr2 ${ }^{\mathrm{RFP}}$ mice and immunohistochemical staining for the pan-neuronal marker, protein gene product 9.5 (PGP9.5), or the sensory neuron marker, calcitonin gene-related peptide (CGRP), were used to visualize the location of CCR2 on intra-articular afferents.

Results: WT, but not CCr2 null, mice displayed knee hyperalgesia 2-16 weeks after DMM. CCR2RA administered i.p. alleviated established hyperalgesia in WT mice 4 and 8 weeks after surgery. Intra-articular injection of CCL2 excited sensory neurons in the L4-DRG, as determined by in vivo calcium imaging; responses to CCL2 increased in mice 20 weeks after DMM. CCL2, but not vehicle, injected i.a. rapidly caused transient knee hyperalgesia in naïve WT, but not CCr2 null, mice. Intra-articular CCR2RA injection also alleviated established hyperalgesia in WT mice 4 and 7 weeks after surgery. CCL2 protein was elevated in the knees of both WT and Ccr2 null mice 4 weeks after surgery. Co-expression of CCR2 and PGP9.5 as well as CCR2 and CGRP was observed in the lateral synovium of naïve mice; co-expression was also observed in the medial compartment of knees 8 weeks after DMM.

Conclusions: The findings suggest that CCL2-CCR2 signaling locally in the joint contributes to knee hyperalgesia in experimental OA, and it is in part mediated through direct stimulation of CCR2 expressed by intra-articular sensory afferents.

Keywords: Osteoarthritis, Hyperalgesia, Sensitization, Pain, CCR2, CCL2, Animal model

\footnotetext{
* Correspondence: Rachel Miller@rush.edu

'Department of Internal Medicine, Division of Rheumatology, Rush University Medical Center, 1735 W Harrison St, Room 714, Chicago, IL 60612, USA

Full list of author information is available at the end of the article
}

(c) The Author(s). 2021 Open Access This article is licensed under a Creative Commons Attribution 4.0 International License, which permits use, sharing, adaptation, distribution and reproduction in any medium or format, as long as you give appropriate credit to the original author(s) and the source, provide a link to the Creative Commons licence, and indicate if changes were made. The images or other third party material in this article are included in the article's Creative Commons licence, unless indicated otherwise in a credit line to the material. If material is not included in the article's Creative Commons licence and your intended use is not permitted by statutory regulation or exceeds the permitted use, you will need to obtain permission directly from the copyright holder. To view a copy of this licence, visit http://creativecommons.org/licenses/by/4.0/ The Creative Commons Public Domain Dedication waiver (http://creativecommons.org/publicdomain/zero/1.0/) applies to the data made available in this article, unless otherwise stated in a credit line to the data. 


\section{Background}

The $\mathrm{C}-\mathrm{C}$ chemokine receptor type 2, CCR2, is a seventransmembrane domain G-protein coupled receptor (GPCR) that acts as the receptor for the $\mathrm{C}-\mathrm{C}$ motif chemokine ligands (CCL), CCL2, CCL7, and CCL12 [1]. CCL2-CCR2 signaling is potently chemotactic for monocytes and immune cells, and since CCR2 is a GPCR, it provides a pharmacologically tractable target $[2,3]$.

In the field of rheumatology, CCR2 has received a great deal of attention as a potential target especially for inflammatory arthritis, because of its well-documented pro-inflammatory and chemotactic actions [4]. CCR2 has also been explored as a target in osteoarthritis (OA) [5]. OA is the most common form of arthritis, affecting 27 million people in the USA [6]. The disease is characterized by progressive joint damage, associated with chronic pain and disability [7]. Disease-modifying OA drugs (DMOADs) that slow down or halt the progression of joint damage and at the same time manage symptoms, do not yet exist [8]. A broad range of analgesic therapies is available to patients, but the most commonly prescribed painkillers suffer from lack of efficacy and problems with side effects or addiction. Therefore, chronic OA pain is often inadequately controlled and constitutes a major health problem [9]. Hence, extensive efforts in academia and industry are focused on identifying safe new targets for OA pain $[10,11]$.

Increasingly, experimental evidence suggests that innate immunity and low-grade inflammation contribute to the pathogenesis of OA [12], providing a solid rationale for exploring CCR2 as a pharmacological target for this disease. Studies in rodent models of OA, however, that aimed to inhibit CCR2 signaling either through genetic ablation of $\mathrm{Ccr} 2$ or through pharmacological blockade with a CCR2 receptor antagonist (CCR2RA) have been largely disappointing, showing no or limited protection from joint damage (reviewed in [5]). Yet, at the same time, studies in a mouse model where experimental OA is induced by surgical destabilization of the medial meniscus (DMM) revealed that CCR2 signaling may be essential for OA-associated pain [13-15]. Indeed, several laboratories have reported a substantial contribution of CCL2-CCR2 signaling to pain-related behaviors associated with progressive joint damage after DMM surgery, including persistent mechanical allodynia, locomotive deficits, and weightbearing deficits (reviewed in [5]).

Pain is sensed by specialized afferent neurons, called nociceptors, that innervate the skin and internal tissues, including joints [16]. Nociceptors are activated by noxious stimuli, such as heat, acid, or a painful mechanical stimulus [17] through an array of specialized receptor channels [18]. For example, transient receptor potential cation channel vanilloid 1 (TRPV1) is activated by noxious heat [19], acid-sensing ion channel (ASIC) is activated by acid [20], and Piezo-type mechanosensitive ion channel component 2 (PIEZO2) is activated by noxious mechanical stimuli [21]. Activation of these receptors results in the generation of action potentials, propagated by ion channels such as voltage-gated sodium channels like $\mathrm{Na}_{V} 1.8$ and $\mathrm{Na}_{V} 1.7$ [18]. These action potentials carry the painful signal along the axon to the cell bodies in the dorsal root ganglia (DRG), and onward to the dorsal horn of the spinal cord, where the first synapse occurs with second-order neurons in the central nervous system (CNS) [17]. In addition to these specialized channels, nociceptors also express receptors for ligands that are present as part of an inflammatory response, such as receptors for cytokines, chemokines, nerve growth factor (NGF) [18] and Toll-like receptors (TLRs) [22, 23]. Thus, many mediators present in the inflammatory milieu can have excitatory effects on nociceptive neurons. This has been well documented for CCL2 (also known as monocyte chemoattractant protein 1 or MCP-1) which, upon binding of CCR2 expressed by DRG neurons, causes rapid excitation through the transactivation of TRPV1 and other ion channels [24]. Concordantly, CCL2 elicits rapid pain behaviors when injected into the paw [24]. In addition to these direct neuronal effects, CCR2 signaling may contribute to painful responses in the context of tissue injury through recruiting macrophages and other immune cells to the injured site, and these cells in turn become local sources of pro-inflammatory, algogenic molecules, further establishing a painful vicious cycle [25].

In the context of OA, studies in the DMM model have revealed that protection from persistent pain in $\mathrm{Ccr} 2$ null mice is associated with reduced infiltration by macrophages in the DRGs [13]. We also showed that cell bodies of sensory neurons in knee-innervating L4-DRGs have increased expression of CCR2 after DMM surgery [13]. However, to date, it is not known if CCR2 is expressed on afferents that are located intra-articularly in joint tissues and if direct activation of these receptors by locally produced CCL2 might contribute to joint pain. Here, we set out to address this question using healthy naïve mice and mice with experimental $\mathrm{OA}$ induced by DMM surgery.

\section{Methods}

\section{Animals}

For these studies, a total of 170 mice were used. All animal experiments were approved by the Institutional Animal Care and Use Committee at Rush University Medical Center. Animals were housed with food and water ad libitum and kept on 12-h light cycles. Wild type (WT) C57BL/6 J male mice were bred at Rush. Ccr2 null mice on a C57BL/6 J background were obtained from Taconic Farms (\#3736). Pirt-GCaMP3 mice were 
received as a gift from Dr. Xinzhong Dong and bred at Rush. These knock-in mice express the fluorescent calcium indicator GCaMP3 in 90\% of all DRG sensory neurons, and not in other peripheral or central tissues, through the Pirt promoter [26]. Ccr2 null $\times$ PirtGCaMP3 mice were generated through two back-crosses at Rush. $C c r 2^{\mathrm{RFP}}$ mice were obtained from the Jackson Laboratory (\#017586).

\section{Surgery}

DMM surgery was performed in the right knee of 10week old male WT or Ccr2 null mice as previously described [13, 27]. In brief, after medial parapatellar arthrotomy, the anterior fat pad was dissected to expose the anterior medial meniscotibial ligament, which was severed. The knee was flushed with saline and the incision closed. Sham surgery was identical to DMM except that the medial meniscotibial ligament remained intact.

\section{Knee hyperalgesia}

Knee hyperalgesia was measured using a Pressure Application Measurement (PAM) device (Ugo Basile, Varese, Italy), as previously described [28]. Briefly, mice were restrained by the hand and the hind paw was lightly pinned to make the correct flexion at a similar angle for each mouse. The PAM transducer was pressed against the medial side of the knee and pressure applied against the knee. PAM software guided the user to apply a constantly increasing force $(30 \mathrm{~g} / \mathrm{s})$ up to a maximum of $450 \mathrm{~g}$. If the mouse tried to withdraw its knee, the force at which this occurred was recorded. Two measurements were taken and recorded per knee and the withdrawal force data were averaged. Knee hyperalgesia was assessed before surgery and 2, 4, 8, 12, and 16 weeks after DMM surgery in WT $(n=5)$ and in Ccr 2 null $(n=5)$ mice by an experimenter blinded to the mouse strain.

\section{Effect of systemically delivered CCR2RA on knee hyperalgesia}

DMM surgery was performed in 10-week old male WT mice. Four, 8, 12, or 16 weeks after DMM surgery, mice received an intraperitoneal (i.p.) injection of CCR2 Receptor Antagonist (CCR2RA, RS 504393, Tocris, $5 \mathrm{mg} /$ $\mathrm{kg})(n=5 \mathrm{mice} /$ time point $)$ or vehicle control $(100 \%$ $\left.\mathrm{DMSO}_{4}\right)(n=4$ mice/time-point). Knee hyperalgesia was assessed right before injection, and again 1,2 , and $3 \mathrm{~h}$ after injection, by an experimenter blinded to the groups.

\section{Effect of locally delivered CCL2 on knee hyperalgesia}

An independent set of 10-week old naïve WT and Ccr2 null mice were injected i.a. with either CCL2 (500 ng in $0.1 \%$ BSA suspended in $5 \mu \mathrm{L}$ PBS) (479-JE-010/CF, R\&D Systems) ( $n=11 \mathrm{WT}$ and $n=5$ Ccr 2 null mice) or vehicle $(0.1 \%$ BSA suspended in $5 \mu \mathrm{L}$ PBS) $(n=11 \mathrm{WT}$ and $n=4$ Ccr 2 null mice). Knee hyperalgesia was assessed right before injection, and 1, 2, and $4 \mathrm{~h}$ after injection, and again $24 \mathrm{~h}$ after injection by an experimenter blinded to the groups.

\section{Effect of locally delivered CCR2RA on knee hyperalgesia} DMM surgery was performed in 10-week old male WT mice, and 4 and 7 weeks later, CCR2RA (BMS CCR2 22, $\mathrm{R} \& \mathrm{D}$ Systems) was injected intra-articularly (i.a.) (0.5 $\mathrm{mg} / \mathrm{kg}$ in $50 \%$ ethanol) ( $n=4$ at 4 weeks, $n=6$ at 7 weeks) or vehicle (50\% ethanol) $(n=4$ at $4 \mathrm{wk}, n=6$ at 7 weeks) using independent set of WT mice after DMM surgery. The injected volume was $5 \mu \mathrm{L}$ (target concentration: $0.5 \mathrm{mg} / \mathrm{kg}$ body weight). Knee hyperalgesia was assessed right before injection, and again 1, 2, and $4 \mathrm{~h}$ after injection, by an experimenter blinded to the mouse strain.

\section{CCL2 protein levels in whole knee joint extracts}

Sham or DMM surgery was performed in 10-week old male WT or Ccr2 null mice. Naïve WT mice were also used. Four or 8 weeks after surgery, ipsilateral knee joints were collected and flash frozen. The entire knee joint was collected, including femoral condyles and tibial plateaux, with the knee joint kept intact; attached tissues (skin, muscle) were removed. Protein extraction was achieved by grinding the knee joint under liquid nitrogen, incubating the tissue in lysis buffer with protease inhibitors overnight at $4{ }^{\circ} \mathrm{C}$, and reserving the supernatants. CCL2 protein levels were measured by ELISA (R\&D system) and normalized to total protein (bicinchoninic acid (BCA) assay, Thermo Scientific). ( $n=4$ mice naïve WT 14 weeks old; $n=6 \mathrm{WT}$ sham $+4 ; n=11 \mathrm{WT}$ $\mathrm{DMM}+4 ; n=4$ naïve WT 18 weeks old; $n=5 \mathrm{WT}$ sham $+8 ; n=11$ WT DMM + 8; $n=6$ Ccr2 null naïve 10 weeks old; $n=8$ Ccr 2 null DMM $+4 ; n=5$ Ccr 2 null $\mathrm{DMM}+8)$.

\section{In vivo calcium imaging}

In study 1 , naïve adult male mice, age $14-26$ weeks $(n=$ 8 Pirt-GCaMP3 $^{+/-} ; n=8$ Ccr 2 null $^{-/-} \times$Pirt$\mathrm{GCaMP}^{+/-}$) were used. In study 2 , adult male $\mathrm{Na}_{\mathrm{V}} 1.8$ cre $\times$ GCaMP6s loxp mice were used (naïve mice, age 21 weeks $(n=6)$ and DMM mice 20 weeks after surgery $(n=8))$. All mice were deeply anesthetized using isoflurane $\left(1.5-2 \%\right.$ in $\left.\mathrm{O}_{2}\right)$, a laminectomy from vertebrae L2L6 was performed, and the right-side L4 dorsal root ganglion (DRG) was exposed [29]. This DRG contains most of the sensory neurons that innervate the mouse knee joint [30, 31]. Silicone elastomer (World Precision Instruments) was used to cover the exposed DRG and surrounding tissue to avoid drying [32]. The mouse was positioned under a Prairie Systems Ultima In Vivo two 
photon microscope on a custom stage, using Narishige spinal clamps to slightly elevate the mouse in order to avoid motion artifacts associated with breathing. A Coherent Chameleon-Ultra2 Ti:Sapphire laser was tuned to $920 \mathrm{~nm}$, and GCaMP3 or GCaMP6 signal was collected by using a bandpass filter for the green channel (490 to $560 \mathrm{~nm}$ ). Image acquisition was controlled using PrairieView software version 5.3. Images of the L4 DRG were acquired at $0.7 \mathrm{~Hz}$, with a dwell time of $4 \mu \mathrm{s} /$ pixel (pixel size $1.92 \times 1.92 \mu \mathrm{m}^{2}$ ), and a $10 \times$ air lens (Olympus UPLFLN U Plan Fluorite, $0.3 \mathrm{NA}, 10 \mathrm{~mm}$ working distance). The scanned sample region was $981.36 \times$ $981.36 \mu \mathrm{m}^{2}$. Anesthesia was maintained using isoflurane (1.5-2\%) during imaging. For each mouse, a 30 G needle connected to a Hamilton syringe was inserted into the intra-articular space of the knee joint, imaging was started, $7 \mu \mathrm{L}$ vehicle $(0.1 \%$ BSA in PBS) was injected from frame 20-25, imaging continued until frame 100, and the needle was removed. After a 5-min recovery period, the process was repeated: a $30 \mathrm{G}$ needle connected to a Hamilton syringe was inserted into the intraarticular space of the knee joint, imaging was started, $7 \mu \mathrm{L}$ recombinant CCL2 (700 ng) was injected from frame 20-25, imaging continued until frame 100, and the needle was removed. Pilot experiments confirmed that repeated injections of saline did not induce responses. In addition, as a positive control, neuronal responses to a $200 \mathrm{~g}$ force applied to the ipsilateral hind paw were confirmed [29] prior to proceeding with the rest of the experiment. For each mouse, changes in $\left[\mathrm{Ca}^{2+}\right]_{\mathrm{i}}$ were quantified using a custom ImageJ macro to calculate the change in fluorescence in each frame $t$ of a time series using the formula: $\Delta \mathrm{F} / \mathrm{Fo}$, where $\mathrm{Fo}$ is the average intensity of the baseline period ( 15 frames) prior to injection [29]. Sensory neuron responses to either vehicle or to CCL2 were identified as cells having peak $\Delta \mathrm{F} / \mathrm{Fo}$ values during or after the application period that was greater than 4 times the standard deviation of the baseline period [32]. The total number of neurons imaged for each DRG was estimated by counting the number of neurons within a region of average density and extrapolating to the total imaged area (mean \pm SEM: Pirt-GCaMP3 $=280 \pm 36$ neurons; Ccr 2 null $\times$ PirtGCaMP3 $=278 \pm 17$ neurons; naïve $\mathrm{Na}_{\mathrm{V}} 1.8$-GCaMP6s $=$ $321 \pm 38$ neurons; DMM Na $1.8-G C a M P 6 s=323 \pm 33$ neurons). The percentage of responses to either vehicle or to CCL2 was calculated using the formula: \# responses / \# total neurons imaged $\times 100$.

\section{Knee immunohistochemistry}

Ten-week-old male naïve $C c r 2^{\mathrm{RFP}}$ mice $(n=7)$ or $C c r 2^{R F P}$ mice 8 weeks after DMM surgery $(n=3)$ were perfused transcardially with phosphate-buffered saline (PBS) followed by $4 \%$ paraformaldehyde (PFA) in PBS. The right knees were collected, post-fixed in PFA, decalcified in 14\% EDTA and cryo-preserved in $30 \%$ sucrose. Twenty- $\mu$ m-thick coronal sections were cut throughout the whole joint using the cryostat. Mid-joint sections were collected as previously described [33]. The mid-joint region comprises about 400- $\mu$ m-thick region (20 sections) and was defined as the area where the meniscal horn is devoid of any ligament attachments. These sections were immunostained for protein gene product 9.5 (PGP9.5), a pan neuronal marker (rabbit polyclonal antibody, SAB4503057, Sigma) ( $n=4$ naïve mice), or for calcitonin gene-related peptide (CGRP) (rabbit polyclonal antibody, 24112, ImmunoStar), a marker for a subset of nociceptors ( $n=3$ naïve and $n=3 \mathrm{DMM}+8$ weeks mice) [34-36]. Knee sections were blocked with $5 \%$ goat serum and $0.1 \%$ triton $\mathrm{X}-100$ in PBS for $1 \mathrm{~h}$ at room temperature, then incubated overnight with primary antibodies against PGP9.5 (1:100) or CGRP (1:200) at $4{ }^{\circ} \mathrm{C}$, followed by a secondary antibody, goat anti-rabbit conjugated Alexa Fluor 633 (Molecular Probes; 1: 500). Sections were then imaged using a laser-scanning confocal microscope (Olympus IX70) with independent lasers used to excite the red and far red channels. Images were processed using Fluoview software (FV10-ASW 4.2 Viewer). All images were treated the same in terms of adjustments to brightness and contrast to minimize bias. Channels observed in the subchondral bone of the medial femoral condyles and tibial plateaux that contained CGRP+ and CCR2+/CGRP+ nerves were quantified as previously described [33]: two midjoint sections $(80 \mu \mathrm{m}$ apart) per knee were used to count CGRP+ and CCR2+/CGRP+ channels; counts were averaged for each knee and compared with naïve mice.

\section{Statistical analysis}

For knee hyperalgesia data, a one-way ANOVA with Bonferroni post-test was used to compare time points after DMM surgery in WT or Ccr2 null mice to time 0. For knee hyperalgesia experiments testing injection of CCR2-RA or injection of CCL2, a repeated measures two-way ANOVA with Bonferroni post-test was applied to compare mice treated with vehicle to mice treated with CCR2RA or CCL2 at each time point. For in vivo calcium imaging, the number of sensory neuron responses to CCL2 was compared to the number of responses to vehicle for each strain of mice by paired twotailed $t$ test. In addition, for $\mathrm{Na}_{\mathrm{V}} 1.8-\mathrm{GCaMP} 6 \mathrm{~s}$ mice, the number of sensory neuron responses to CCL2 was compared between naïve and DMM mice by unpaired twotailed $t$ test. For knee protein extracts, data were analyzed by one-way ANOVA with Tukey post-test to compare treatment groups at each time point. For immunohistochemical analysis of osteochondral channels, the number of channels with nerves was compared between naïve and DMM mice by unpaired two-tailed $t$ test. Statistical analyses were done using GraphPad 
Prism version 8.2.1 for Mac (GraphPad Software, San Diego, CA). Results are presented as mean \pm SEM.

\section{Results}

Wild type mice but not Ccr2 null mice develop primary knee hyperalgesia after DMM surgery

Confirming our previous findings [28, 37], WT mice $(n=5)$ developed knee hyperalgesia 2 weeks after DMM surgery, which gradually recovered by week 16 (Fig. 1a; $p<0.0001$ for 4-12 weeks after surgery compared to pre-surgery; $p=$ 0.0041 for 16 weeks after surgery compared to pre-surgery). In contrast, $C c r 2$ null mice $(n=5)$ did not develop hyperalgesia up to 16 weeks after DMM (Fig. 1b). These findings suggest that CCR2 signaling is essential for development of knee hyperalgesia after DMM surgery. In order to assess the role of CCR2 signaling at different stages of the model, we tested the effect of systemically administered CCR2RA, which blocks CCR2 signaling, on established knee hyperalgesia at different time points after DMM. DMM surgery was performed in 10-week old WT mice $(n=9)$. CCR2RA (RS504393, $5 \mathrm{mg} / \mathrm{kg}) \quad(n=5$ mice) or vehicle control $\left(\mathrm{DMSO}_{4}\right)(n=4$ mice) was injected i.p., 4, 8, or 16 weeks after surgery, and knee hyperalgesia was assessed. Four weeks after DMM surgery, hyperalgesia in the operated knee was reversed $1 \mathrm{~h}$ after CCR2RA injection ( $p<0.0001$ vs. vehicle) (Fig. 2a); 8 weeks after surgery, CCR2RA reversed hyperalgesia 1 and $2 \mathrm{~h}$ after administration $(p<0.0001$ at $1 \mathrm{~h}$ and $p=$ 0.008 at $2 \mathrm{~h}$ vs. vehicle) (Fig. 2b). Sixteen weeks after DMM surgery, there was no difference between the vehicle control and treatment groups (Fig. 2c) ( $p>0.99$ at $1 \mathrm{~h}$ and $p=0.46$ at $2 \mathrm{~h}$ vs. vehicle).

\section{CCL2 injection into the knee joint cavity directly excites} sensory afferents and results in transient knee hyperalgesia in WT but not in Ccr2 null mice

In order to assess the direct contribution of neuronal CCR2 to development of knee hyperalgesia, we assessed rapid-onset effects of i.a. injection of CCL2 into the knee joint space. We have previously shown that approximately $15 \%$ of all sensory neurons located in the L4DRG innervate the knee joint [29]. Here, we assessed whether i.a. injection of CCL2 into a healthy mouse knee can directly excite those sensory neurons, through in vivo calcium imaging of the L4-DRG. We found that injecting vehicle into the knee cavity of naïve PirtGCaMP3 mice elicited a response in a very small number of neurons ( 8 mice, $0.26 \pm 0.1 \%$ of L4-DRG neurons), while injecting CCL2 elicited responses in an increased percentage of sensory neurons ( $1.1 \pm 0.25 \%$ of neurons) (Fig. 3a; $p=0.02$ ). Figure $3 \mathrm{~b}$ represents an example response, showing an increase in transient $\left[\mathrm{Ca}^{2+}\right]_{\mathrm{i}}$ following injection of CCL2. In contrast, $C c r 2$ null $\times$ PirtGCaMP3 mice showed a similar percentage of neuronal responses to vehicle and CCL2 injections (Fig. 3c; $n=8$; vehicle: $0.63 \pm 0.11 \%$; CCL2: $0.68 \pm 0.13 \%, p=0.68$ ).

In order to assess whether responses to CCL2 change after DMM surgery, we used $\mathrm{Na}_{\mathrm{v}} 1.8$ cre $\times$ GCaMP6s loxp mice to measure CCL2 elicited responses specifically in nociceptors in naïve mice and in mice 20 weeks after DMM surgery. We found that a similar percentage of neurons responded to i.a. CCL2 in naïve $\mathrm{Na}_{\mathrm{V}} 1.8$ GCaMP6s mice $(0.74 \pm 0.33 \%$ of neurons) compared to naïve Pirt-GCaMP3 mice. In addition, after DMM surgery, the percentage of neurons responding to CCL2 increased compared to naïve mice $(2.6 \pm 0.66 \%$ of neurons; $p=0.04$ ) (Fig. 3d).

The ability of locally administered CCL2 to directly activate sensory neurons upon i.a. injection suggests that this chemokine may be able to cause rapid-onset knee hyperalgesia upon local injection. We tested this experimentally by injecting CCL2 into the knees of naive WT mice. CCL2 $(100 \mathrm{ng} / \mu \mathrm{L}$ in $5 \mu \mathrm{l})$ or vehicle $(5 \mu \mathrm{L} \mathrm{PBS}+0.1 \%$ BSA) was injected i.a. into the right knee of 9-week-old male naïve WT mice (11 mice/group). Knee hyperalgesia was assessed right before injection and then 1,2 , and $4 \mathrm{~h}$ after administration of CCL2, and again $20 \mathrm{~h}$ later.
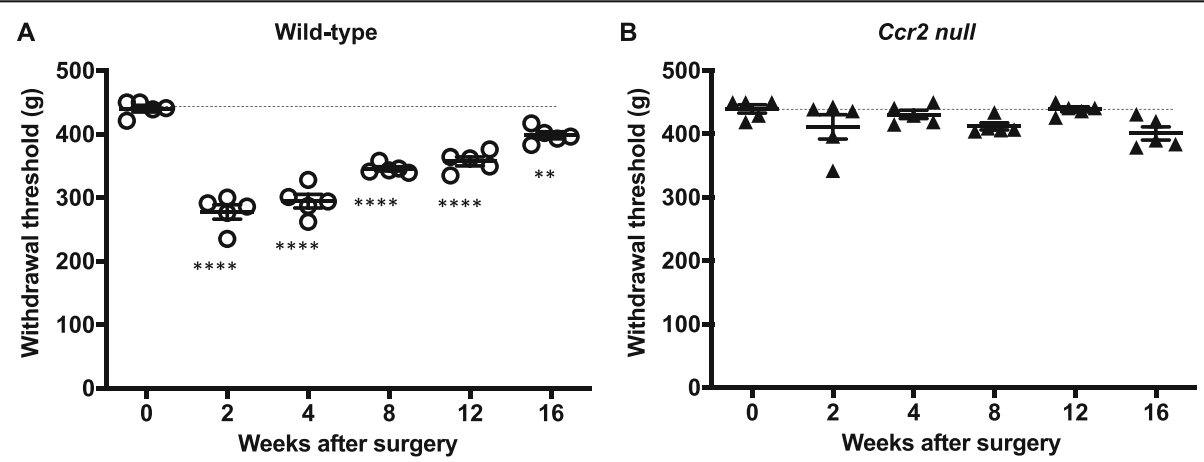

Fig. 1 Knee hyperalgesia after DMM surgery. a WT $(n=5)$ mice and $\mathbf{b} \mathrm{Ccr} 2$ null mice $(n=5)$. The withdrawal threshold baseline is indicated by the dashed line. ${ }^{* *} p<0.01,{ }^{* * *} p<0.0001$ vs time 0 . One-way ANOVA with Bonferroni's multiple comparisons test to compare each time point to its respective time 0 . Mean \pm SEM 

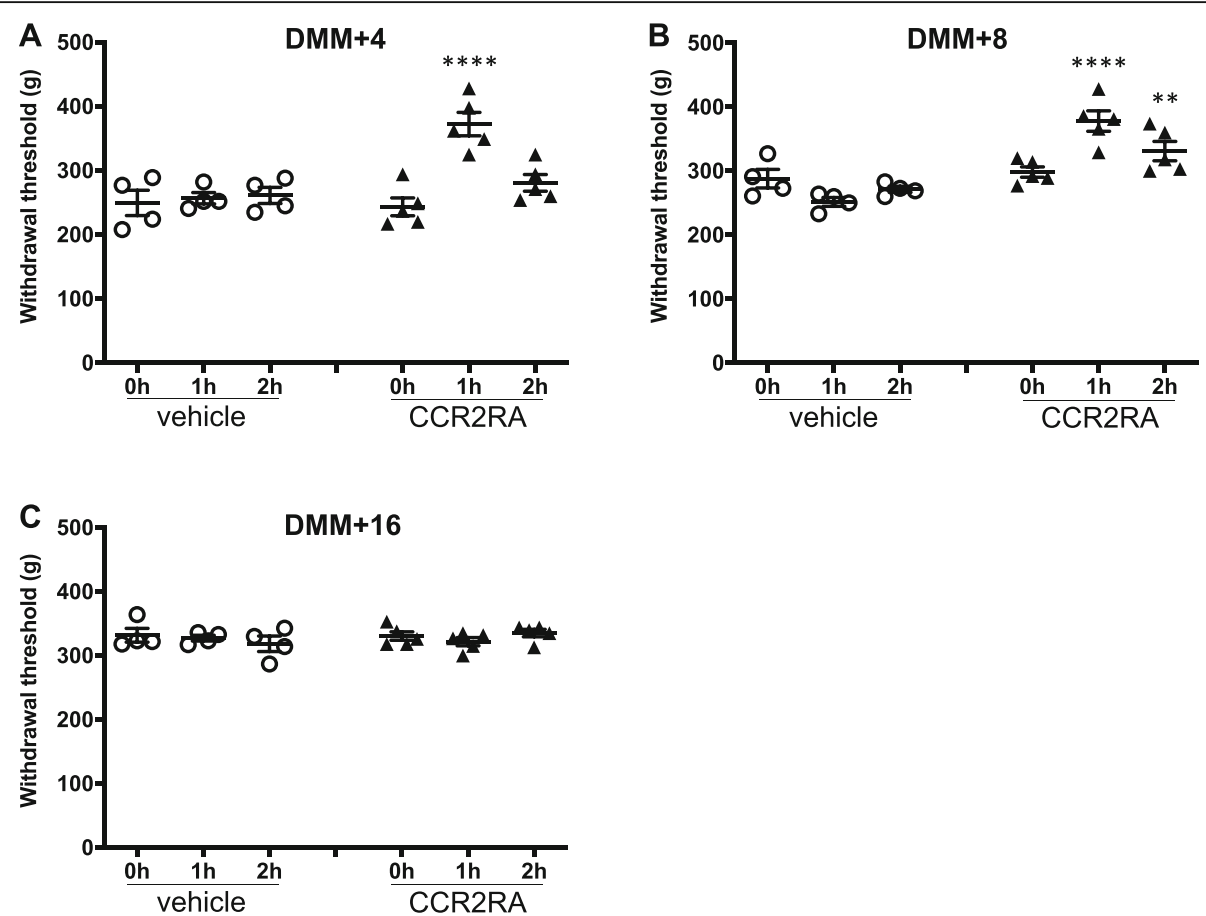

Fig. 2 CCR2RA delivered systemically at different time points after DMM surgery. a 4, b 8, and c 16 weeks after DMM surgery, CCR2RA (RS504393, Tocris: $5 \mathrm{mg} / \mathrm{kg}$, i.p., $n=5)$ or vehicle control $\left(100 \% \mathrm{DMSO}_{4}\right.$, i.p., $\left.n=4\right)$ was systemically administered and knee hyperalgesia was measured before injection, $1 \mathrm{~h}$ after, and $2 \mathrm{~h}$ after injection. ${ }^{* *} p<0.01,{ }^{* * *} p<0.0001$ vs vehicle. Repeated measures two-way ANOVA with Bonferroni's multiple comparisons test to compare CCR2-RA to vehicle at each time point. Mean \pm SEM

Injecting CCL2 into the knee cavity resulted in knee hyperalgesia 1 and $2 \mathrm{~h}$ later, compared to vehicle control (Fig. $4 \mathrm{a}, p=0.03$ at $1 \mathrm{~h} ; p=0.001$ at $2 \mathrm{~h}$; CCL2 vs. vehicle). The withdrawal threshold recovered to baseline by $24 \mathrm{~h}$ after CCL2 injection (Fig. 4a). The rapid onset of knee hyperalgesia after i.a. injection suggests this is a direct, neuronally mediated effect. In order to establish that this was a specific CCR2 signaling mediated effect, we repeated the same experiment in 9-week-old naive male $C c r 2$ null mice. We found that vehicle ( $n=4$ mice) or $500 \mathrm{ng}$ CCL2 ( $n=5$ mice) injection were not capable of triggering knee hyperalgesia in Ccr2 null mice at any time up to $24 \mathrm{~h}$
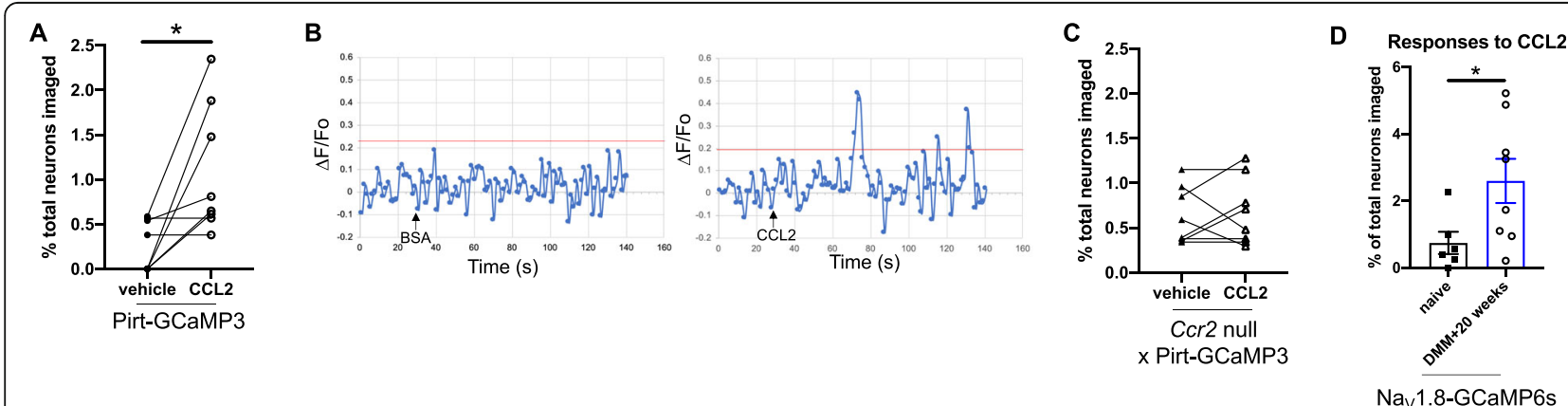

Fig. 3 In vivo calcium imaging testing neuronal responses to i.a. injection of vehicle (7 $\mu \mathrm{L}, 0.1 \%$ BSA in PBS) or CCL2 (7 $\mu \mathrm{L}$, \#MJE00, R\&D systems, 700 ng). a Percentage of neurons that responded to vehicle or CCL2 in naïve Pirt-GCaMP3 mice. Each dot $=$ one mouse. $n=8 ; \mathbf{b}$ Example $\triangle F / F o$ plots are shown to depict how responses were determined. This neuron responded to CCL2 but not to BSA in a naïve Pirt-GCaMP3 mouse (this mouse had $0 \%$ vehicle responses and $1.5 \%$ CCL2 responses); Red line indicates the threshold for response $=4 \times$ standard deviation of the first 15 frames; Each dot indicates an imaging frame - the connecting line is included for ease of viewing peaks. c Percentage of neurons that responded to vehicle or CCL2 in naïve CCr2 null $\times$ Pirt-GCaMP3 mice. $n=8$; Mean \pm SEM. Paired two-tailed $t$ test, ${ }^{*} p<0.05$. $\mathbf{d}$ Percentage of neurons that responded to CCL2 in naïve $(n=6)$ or DMM +20 week $(n=8)$ Nav1.8 cre-GCaMP6s loxp mice. Unpaired two-tailed $t$ test. ${ }^{*} p<0.05$ 

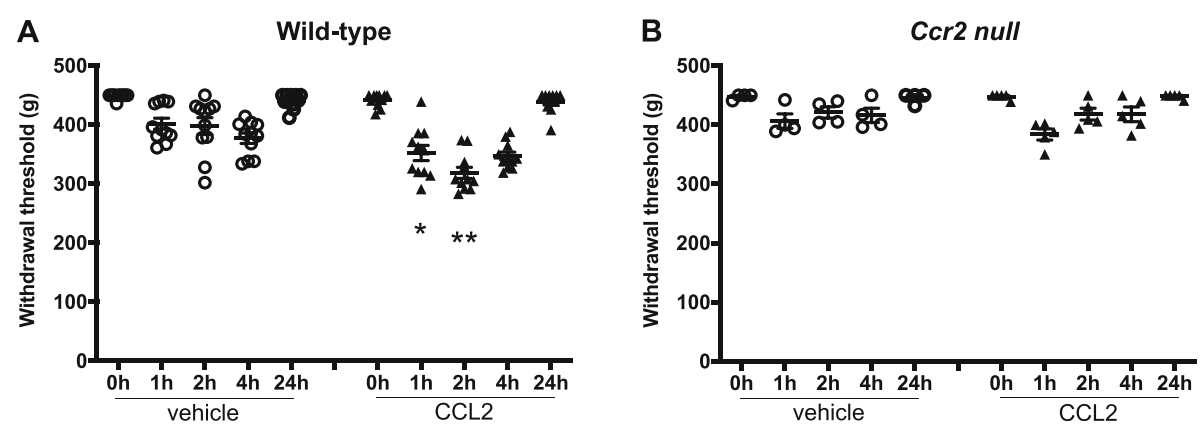

Fig. 4 CCL2 (\#MJE00, R\&D systems, 500 ng $(5 \mu \mathrm{L})$ i.a.) or vehicle ( $5 \mu \mathrm{L}$ of $0.1 \%$ BSA in PBS) injected intra-articularly into a naive wild-type and $\mathbf{b}$ naïve C $\mathrm{Cr} 2$ null mice. Knee hyperalgesia was measured before injection, and 1, 2, 4, and $24 \mathrm{~h}$ after injection. $n=11$ vehicle, $n=11 \mathrm{CCL} 2$ for wildtype; $n=4$ vehicle, $n=5$ CCL2 for $C$ Cr2 null mice. ${ }^{*} p<0.05,{ }^{*} p<0.01$ vs vehicle at the same time point. Repeated measures two-way ANOVA with Bonferroni's multiple comparisons test to compare CCL2 to vehicle at each time point. Mean \pm SEM

(Fig. $4 \mathrm{~b} ; p=0.39$ at $1 \mathrm{~h}, \mathrm{CCL} 2$ vs. vehicle), further suggesting that local CCL2-CCR2 signaling mediates knee hyperalgesia.

\section{Intra-articular administration of CCR2RA reverses knee hyperalgesia after DMM}

In order to further establish whether CCR2 signaling in the joint acts locally to establish knee hyperalgesia in the context of experimental OA, we decided to test the effect of i.a. administered CCR2RA in DMM mice with established knee hyperalgesia. DMM surgery was performed in 10 -week old WT mice ( $n=20$ mice), and CCR2RA (BMS CCR2 22, $0.5 \mathrm{mg} / \mathrm{kg}$ ) or vehicle control (50\% ethanol) was injected i.a. into the knee joint, 4 weeks $(n=4$ vehicle and $n=4$ CCR2RA) and 7 weeks ( $n=6$ vehicle and $n=6$ CCR2RA) after surgery. Four weeks after DMM, i.a. injection of CCR2RA, but not vehicle, reversed established knee hyperalgesia by $1 \mathrm{~h}$ after injection ( $p=0.0029$ vs. vehicle) (Fig. 5a). Knee hyperalgesia returned $4 \mathrm{~h}$ after injection (Fig. 5a). Seven weeks after DMM surgery, the maximum effect of CCR2RA was observed $2 \mathrm{~h}$ after injection ( $p=0.007$ vs. vehicle) and knee hyperalgesia returned by $4 \mathrm{~h}$ after the injection (Fig. 5b).

\section{CCL2 protein is elevated in whole joint extracts 4 weeks} after DMM in WT and in Ccr2 null mice

Because the previous results suggest that i.a. injection of CCR2RA blocks the effects of locally produced CCL2 in the knee, we measured total CCL2 protein levels in the knees of WT mice, 4 and 8 weeks after sham or DMM surgery in the right knees. Four weeks after DMM, CCL2 levels were elevated compared to naïve or sham-operated mice ( $p=0.018$ vs. naïve; $p=0.048$ vs. sham), but levels were back to baseline by week 8 (Supp Fig. 1). We also performed DMM surgery in Ccr2 null mice and measured CCL2 levels in whole knee joint extracts. Here, we found that CCL2 levels were also elevated, again peaking 4 weeks after DMM ( $p=0.013$ vs. naive) (Supp Fig. 1).

\section{CCR2 is expressed by intra-articular nociceptors}

In order to visualize the location of CCR2 on intra-articular afferents, $\quad C c r 2^{\text {RFP }}$ mice and
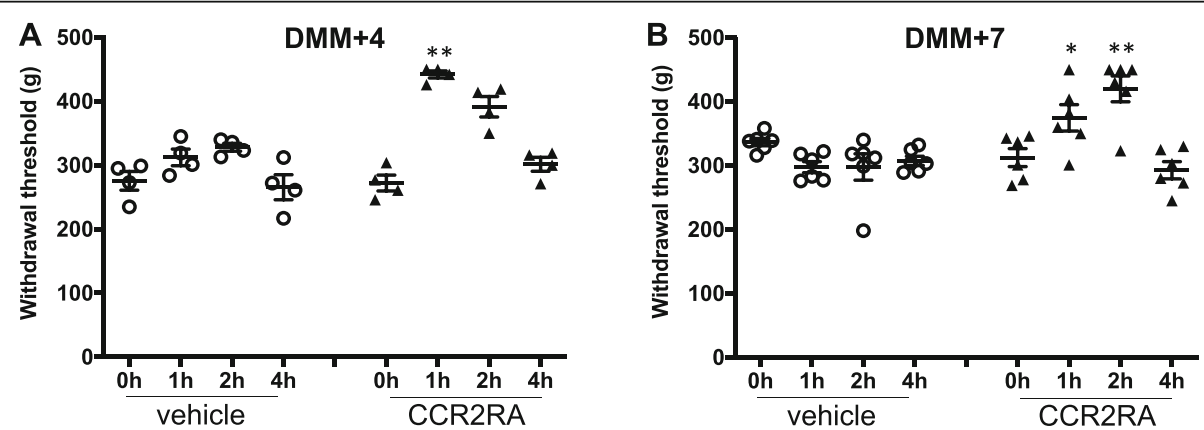

Fig. 5 CCR2RA delivered intra-articularly at different time points after DMM surgery. a Four and $\mathbf{b} 7$ weeks after DMM surgery, CCR2RA (BMS CCR2 22, R\&D systems: $0.5 \mathrm{mg} / \mathrm{kg}$, i.a.) or vehicle control $(50 \% \mathrm{EtOH}$, i.a.) was intra-articularly administered and knee hyperalgesia was measured before injection, and 1, 2, and $4 \mathrm{~h}$ after injection. ( $n=4$ vehicle, $n=4$ CCR2RA at DMM +4 weeks) $\left(n=6\right.$ vehicle, $n=6$ CCR2RA at DMM +7 weeks) ${ }^{*} p<$ $0.05,{ }^{* *} p<0.01$ vs vehicle. Repeated measures two-way ANOVA with Bonferroni's multiple comparisons test to compare CCR2RA to vehicle at each time point. Mean \pm SEM 
immunohistochemical staining for the nociceptor marker, calcitonin gene-related peptide (CGRP), or the pan-neuronal marker, protein gene product 9.5 (PGP9.5), were used. Sections from 10-week-old male naïve $C c r 2^{\mathrm{RFP}}$ mice $(n=3)$ showed overlap between CGRP staining and CCR2-RFP signal in the lateral synovium (Fig. 6 a, b), an area that we have previously shown to have dense nociceptive innervation in naïve mice [33]. In addition, in another set of naïve $C c r 2^{\mathrm{RFP}}$ mice $(n=4)$, we observed some overlap between CCR2 and PGP9.5 signals (Supp. Fig. 2 A-D). No CCR2 signal was seen in the medial synovium (Fig. 6c)-we have previously also demonstrated a lack of nociceptors in this compartment in young naïve mice [33].

Because we have shown that new sensory nerves develop in the medial compartment after DMM surgery [33], we also examined $C c r 2^{\mathrm{RFP}}$ mice 8 weeks after DMM. We found that these mice still had CGRP+ innervation in the lateral synovium, similar to naïve mice, with a subset of fibers showing overlay with CCR2 (Fig. 7 a, b, Supp. Fig. 3). In addition, we found that these mice developed increased numbers of CGRP+ osteochondral channels in the medial compartment compared to naïve controls, as has been reported in rat and human OA [38] (Fig. 7 c, f, Supp. Fig. 3). In addition, a subset of the CGRP+ nerves in these channels also showed overlap with CCR2-RFP signal (Fig. 7e, Supp. Fig. 3), and the number of double-positive CCR2+/CGRP+ channels increased after DMM (Fig. 7g). We also observed some overlap between CGRP and CCR2-RFP in the medial synovium (Fig. 7d, Supp. Fig. 3), in the area where we have seen $\mathrm{Na}_{V} 1.8+$ nerves appear after DMM surgery previously [33].

\section{Discussion}

In this study, we aimed to assess whether CCR2 expressed by intra-articular afferents can respond to CCL2, and how this may relate to knee hyperalgesia. The findings suggest that CCL2-CCR2 signaling locally in the joint contributes to knee hyperalgesia in experimental OA, and the effect is in part mediated through direct stimulation of CCR2 expressed by intra-articular sensory afferents. These findings are of interest for several reasons, discussed below.

First, many studies have reported that levels of chemokines, including CCL2 as well as other CCR2 ligands, CCL7 and CCL8, are elevated in osteoarthritic compared to healthy joints $[39,40]$. CCL2 levels are increased in the synovial fluid of human OA knees, and this has been correlated with symptoms [41, 42]. A recent study reported that CCL2 was one of a panel of 6 synovial fluid biomarkers related to synovial inflammation-specifically to macrophage activation-in $\mathrm{OA}$, as well as to radiographic and symptom severity [43]. Interestingly, several independent studies have reported that, after joint trauma, CCL2 levels in the synovial fluid rapidly increase [44], and levels correlated with pain [44-46]. CCL2 is also increased in the joints in experimental

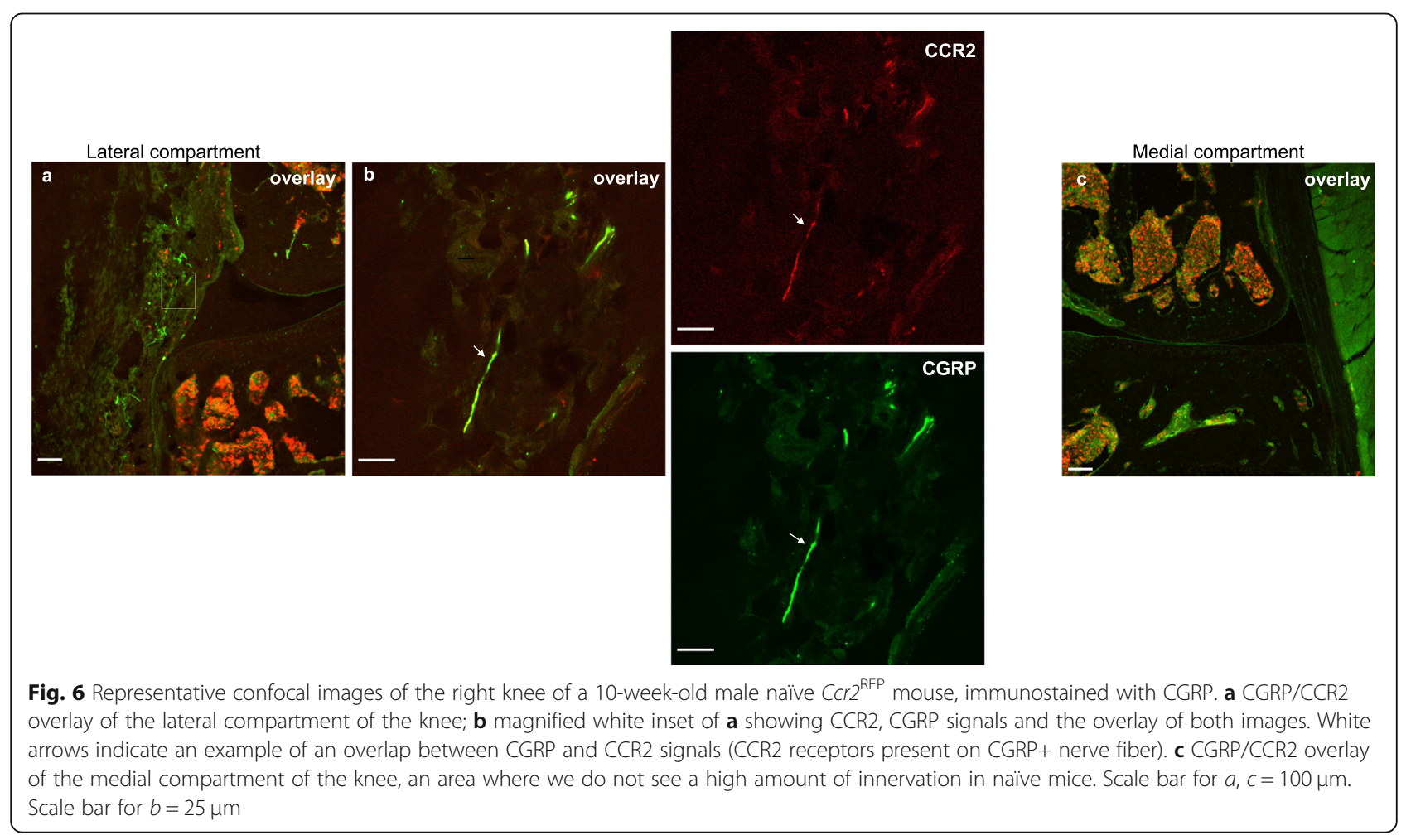




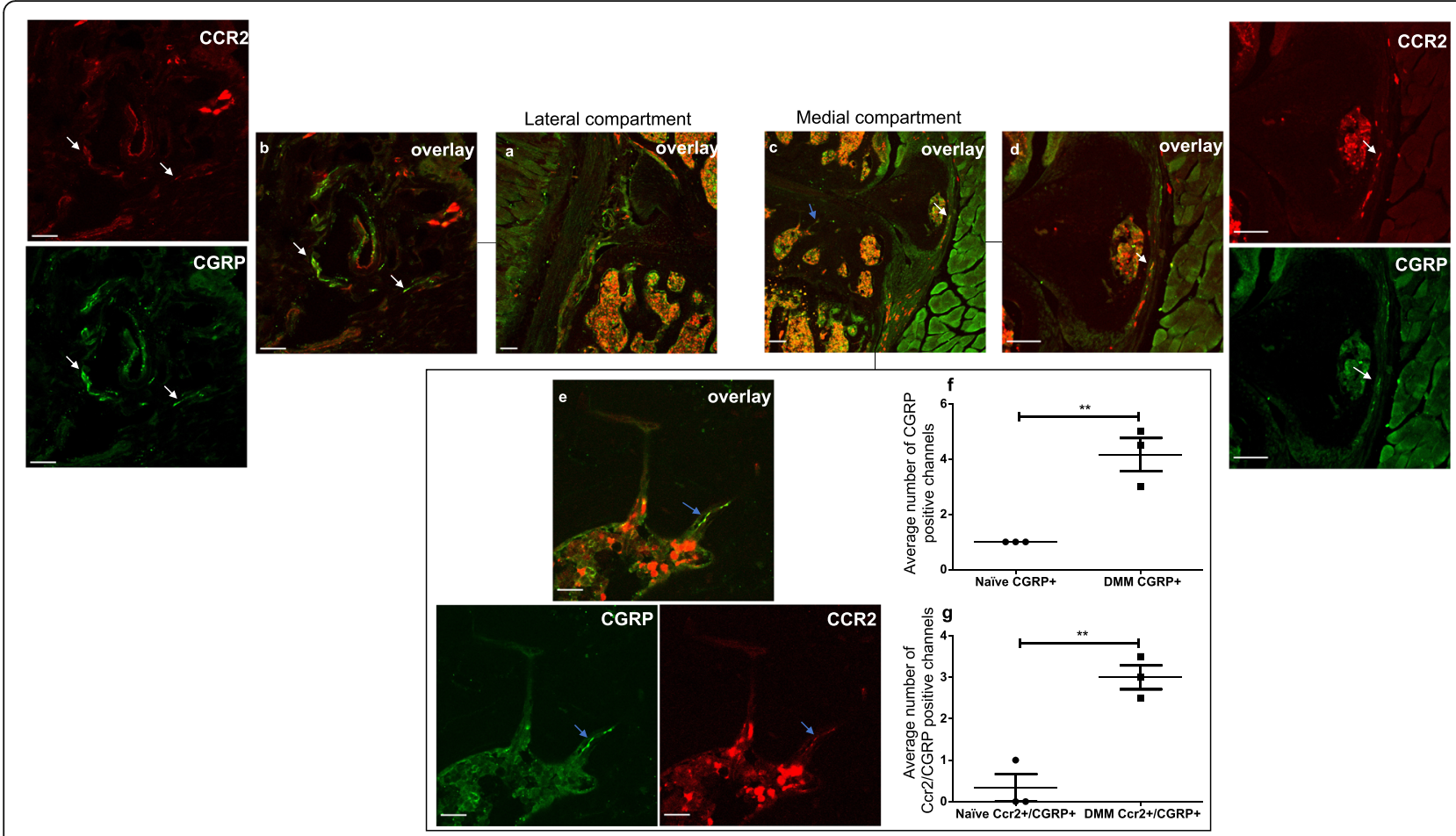

Fig. 7 Representative confocal images of the right knee of a C $\mathrm{Cr} 2^{R F P}$ mouse 8 weeks after DMM surgery, immunostained with CGRP. a CGRP/CCR2 overlay of the lateral compartment of the knee; $\mathbf{b}$ magnified image of a showing CCR2, CGRP signals and the overlay of both images. White arrows indicate an example of overlap between CGRP and CCR2 signals in the lateral synovium (CCR2 receptors present on CGRP+ nerve fibers). c CGRP/CCR2 overlay of the medial compartment of the knee; $\mathbf{d}$, e magnified of $\mathbf{c}$ showing CCR2, CGRP signals and the overlays of both images. c, $\mathbf{d}$ White arrows indicate an example of an overlap between CGRP and CCR2 signal in the medial synovium (CCR2 receptors present on CGRP+ nerve fibers). c, e Blue arrows point to a CGRP/CCR2-positive channel in the medial subchondral bone. $\mathbf{f}$, $\mathbf{g}$ Quantification of the CGRP+ and CCR2+/CGRP+ channels in the subchondral bone of naïve and DMM knees. Unpaired two-tailed $t$ test. Scale bar for $a, c, d=100 \mu \mathrm{m}$. Scale bar for $b, e=25 \mu \mathrm{m} .{ }^{* *} p<0.01$. Mean \pm SEM

models of OA. For example, after DMM surgery, $C c l 2$ is rapidly induced in the joint [15]. In a rat surgical model, Ccl2 was elevated in the cartilage early after surgery [47]. Here, we report increased CCL2 protein in whole knee joint extracts 4 weeks after DMM but not sham surgery. Therefore, this chemokine is a good candidate mediator of the knee hyperalgesia that occurs early on after DMM surgery [28]. Indeed, we found that $\mathrm{Ccr} 2$ null mice were protected from developing knee hyperalgesia after DMM surgery. Furthermore, locally injected CCR2RA reversed ongoing knee hyperalgesia at 4 weeks. CCR2RA was also efficacious in reversing knee hyperalgesia when injected at later stages, i.e., 7 weeks after DMM, when CCL2 levels in the joint are declining. There are several explanations for this observation. For one, there may still be sufficient CCL2 present in specific joint tissues to activate local nociceptors, since many cells can produce this chemokine, including chondrocytes and synoviocytes [39]. Moreover, DRG neurons can also release CCL2 and they increase their production of this chemokine in pain states-for example, we have previously shown that DRG neurons produce more
CCL2 protein 8 weeks after DMM [13]. This indicates the potential existence of a positive autocrine CCR2mediated feedback loop that operates in joint pain. Finally, other CCR2 ligands may be present in the joint at the 7-8 week time point. Indeed, it has been shown by IHC that CCL12 is upregulated in the joint 4,8 , and 12 weeks after DMM surgery [14].

A second observation of interest is that the involvement of CCR2 signaling appears to operate at the level of the joint, since i.a. injection of CCL2 caused rapidonset transient hyperalgesia in WT but not in Ccr2 null mice. Furthermore, this effect is likely mediated through CCR2 expressed by i.a. neurons, as suggested by in vivo calcium imaging experiments showing that neurons in the L4-DRG of naive WT-but not Ccr2 null-mice respond to CCL2 injected into the knee cavity. These experiments were modeled on classical experiments describing that i.a. injection of cytokines such as TNF $\alpha$, IL-1, IL-6, and IL-17 can rapidly activate nerves as demonstrated by in vivo electrophysiology $[48,49]$. This was further strengthened by our finding that CCR2 and CGRP, as well as CCR2 and PGP9.5, co-localized in the 
knee. Reports of expression of specific receptors on i.a. nerves are exceedingly rare [50], and this has not been shown for CCR2. More commonly, i.a. receptor expression is inferred by actions of drugs injected into the knee joint. Description of receptor expression by sensory neurons is usually focused on the cell bodies in the DRGs, as has been shown for CCR2. In addition, a variety of receptors have been shown to be expressed by afferents in the skin [51]. Hopefully, the availability of reporter mice will enable future studies to describe the detailed localization of receptors on peripheral nerve terminals innervating the joint in the course of OA.

We and others have previously shown a role for CCR2 signaling in pain associated with OA joint damage in the DMM model [13]. Specifically, we previously reported that $\mathrm{Ccr} 2$ null mice were protected from persistent pain behaviors in this model [13]. Furthermore, both $\mathrm{Ccr} 2$ null and $C c l 2$ null mice had a delayed onset of weightbearing deficits after DMM surgery [15]. This protection against chronic pain occurred despite $\mathrm{C} c r 2$ null mice developing comparable joint damage as WT mice as well as comparable early upregulation of other inflammatory markers in the knee joint [15]. CCR2RA administered 10 weeks after DMM alleviated locomotor deficits associated with this model [13], and in one study, chronic systemic administration of CCR2RA during the first 4 weeks after DMM inhibited development of weightbearing deficits [14]. Interestingly, this analgesic effect was sustained even at later stages, even when the drug was only administered the first 4 weeks after surgery [14]. The current study is the first to examine the role of this pathway in the development of knee hyperalgesia, which is an indicator of local joint pain and largely an earlystage pain behavior in this model. The findings that locally injected CCR2RA can reverse this behavior 4-7 weeks after surgery, suggest that this pathway may constitute an attractive analgesic target for early stages of disease, for example immediately after joint injury.

Finally, we have recently reported that the nociceptive innervation of the knee is profoundly altered after DMM surgery, both anatomically with the appearance of new nerve endings in the medial compartment [33], and functionally with increased numbers of sensory neurons responding to an applied mechanical force [29]. Here, we provide evidence that a subset of these new nerves also express CCR2 and are more responsive to CCL2 injected into the knee joint, suggesting that CCL2-CCR2 signaling is contributing to this neuroplasticity in OA.

\section{Conclusions}

We have previously demonstrated that CCL2-CCR2 signaling is an important mediator of pain during the development of experimental $\mathrm{OA}$ induced by surgical DMM [13]. In this context, CCR2 signaling may contribute to pain-related responses through recruiting macrophages to the injured joint and to the DRG, as well as through direct neuronal activation. The latter is associated with the expression of both CCL2 and CCR2 by nociceptors in the DRG and resulting CCR2mediated nociceptor excitation. In order to be able to intervene in this process effectively, it is important to elucidate whether algogenic signaling takes place within the knee joint or at the level of the DRG, through intersomatic CCR2 signaling [52]. These two sites are anatomically distinct due to the morphology of DRG neurons. The results of the experiments discussed above now make it clear that, at least during the initial phase after DMM surgery, CCR2 mediated signaling that occurs solely in the knee joint is sufficient to produce DMM-associated hyperalgesia, suggesting that blocking CCR2 responses at peripheral terminals is sufficient to produce analgesic effects in OA. It will be interesting in future experiments to investigate whether chronic administration of CCR2RA is effective in delaying onset of knee hyperalgesia. In addition, reports of expression of specific receptors on intra-articular nerves are exceedingly rare-translationally, it will be important to identify what other druggable receptors are expressed by intra-articular afferents in OA. These observations will help to translate these results into the clinical arena. All our findings point toward a temporally tightly regulated role of this pathway in controlling pain in OA-as every study attempting to define this role has found [5].

\section{Supplementary Information}

The online version contains supplementary material available at https://doi. org/10.1186/s13075-021-02486-y.

\footnotetext{
Additional file 1: Supp Fig. 1. CCL2 protein expression in whole knee joint extracts collected from wild-type (wt) and Ccr2 null mice at different time points after sham or DMM surgery. ( $n=4$ mice wt naïve 14 weeks old; $n=6$ wt sham $+4 ; n=11$ wt $\mathrm{dmm}+4 ; n=4$ wt naïve 18 weeks old; $n=5$ wt sham $+8 ; n=11$ wt $d m m+8 ; n=6$ Ccr2 null naïve 10 weeks old; $n=8 \mathrm{Ccr} 2$ null DMM $+4 ; \mathrm{n}=5 \mathrm{Ccr} 2$ null DMM + 8) ${ }^{*} p<0.05,{ }^{* *} p<0.01$ vs vehicle. One-way ANOVA with Tukey's multiple comparisons test to compare treatment groups at each time point. Mean \pm SEM. Supp. Fig. 2. Representative confocal images of the right knee of a 10-week old male naïve $\mathrm{Ccr} 2^{\text {RFP }}$ mouse, immunostained with PGP9.5. (A,B) Two different magnifications of a representative frontal section demonstrating PGP9.5/ CCR2 overlays within the lateral synovium of the knee; $(C, D)$ magnified white insets of (B) showing CCR2, PGP9.5 signals and the overlays of both images. White arrows indicate the exact areas of the overlap between PGP9.5 and CCR2 signals (CCR2 receptors present on PGP9.5+ nerve fibers). Scale bar for $A, B=100 \mu \mathrm{m}$. Scale bar for the rest of images $=25 \mu \mathrm{m}$. Supp. Fig. 3. Representative confocal images of the right knee of $\mathrm{Ccr}^{\mathrm{RFP}}$ mouse 8 weeks after DMM surgery from a different mouse than shown in Fig. 7, immunostained with CGRP. (a, b) CGRP/CCR2 overlay of the lateral and medial compartments of the knee respectively; (c) magnified of (b) showing CCR2, CGRP signals and the overlay of both images. Blue arrows point to a CGRP+/CCR2+ channel in the medial subchondral bone. (d) magnified of (a) showing CCR2, CGRP signals and the overlays of both images. White arrows point to CGRP+/CCR2+ signal in the lateral synovium. Scale bar for $a, b=100 \mu \mathrm{m}$. Scale bar for $c, d=25 \mu \mathrm{m}$.
} 


\section{Authors' contributions}

S.I. performed all knee hyperalgesia experiments and surgeries and was a major contributor in writing the manuscript. A.O. performed knee immunohistochemistry. D.W. contributed to the acquisition of the in vivo calcium imaging data. D.R. contributed to the acquisition of the in vivo calcium imaging data. R.J.M. contributed to the design and interpretation of the experiments as well as editing of the manuscript. A.M. assisted in the design and interpretation of the experiments and was a major contributor in writing the manuscript. R.E.M. contributed to the design and interpretation of the experiments, performed the in vivo calcium imaging and CCL2 protein expression experiments, and was a major contributor in writing the manuscript. The authors read and approved the final manuscript.

\section{Funding}

Funding from the National Institutes of Health (NIAMS) (K01AR070328 to REM, R01AR060364 to AMM, R01AR064251 to AMM and RJM) supported this work.

\section{Availability of data and materials}

All data generated or analyzed during this study are included in this published article [and its supplementary information files].

\section{Declarations}

\section{Ethics approval and consent to participate}

All animal experiments were approved by the Institutional Animal Care and Use Committee at Rush University Medical Center.

\section{Consent for publication}

Not applicable.

\section{Competing interests}

The authors declare that they have no competing interests.

\section{Author details}

'Department of Internal Medicine, Division of Rheumatology, Rush University Medical Center, 1735 W Harrison St, Room 714, Chicago, IL 60612, USA. 2Department of Physiology, Northwestern University, Chicago, IL 60611, USA. ${ }^{3}$ Department of Pharmacology, Northwestern University, Chicago, IL 60611, USA.

Received: 31 May 2020 Accepted: 22 March 2021

\section{Published online: 07 April 2021}

\section{References}

1. Charo IF, Ransohoff RM. The many roles of chemokines and chemokine receptors in inflammation. N Engl J Med. 2006;354(6):610-21. https://doi. org/10.1056/NEJMra052723.

2. Hauser AS, Attwood MM, Rask-Andersen M, Schioth HB, Gloriam DE. Trends in GPCR drug discovery: new agents, targets and indications. Nat Rev Drug Discov. 2017;16(12):829-42. https://doi.org/10.1038/nrd.2017.178.

3. Zimmermann HW, Sterzer V, Sahin H. CCR1 and CCR2 antagonists. Curr Top Med Chem. 2014;14(13):1539-52. https://doi.org/10.2174/156802661466614 0827144115.

4. Szekanecz Z, Koch AE. Successes and failures of chemokine-pathway targeting in rheumatoid arthritis. Nat Rev Rheumatol. 2016;12(1):5-13. https://doi.org/10.1038/nrrheum.2015.157.

5. Miller RE, Malfait AM. Can we target CCR2 to treat osteoarthritis? The trick is in the timing! Osteoarthr Cartil. 2017;25(6):799-801. https://doi.org/10.1016/j. joca.2017.01.019

6. Lawrence RC, Felson DT, Helmick CG, Arnold LM, Choi H, Deyo RA, Gabriel S, Hirsch R, Hochberg MC, Hunder GG, Jordan JM, Katz JN, Kremers HM, Wolfe F, National Arthritis Data Workgroup. Estimates of the prevalence of arthritis and other rheumatic conditions in the United States. Part II. Arthritis Rheum. 2008;58(1):26-35. https://doi.org/10.1002/art.23176.

7. Block JA, Scanzello CR. Osteoarthritis, vol. 25th ed. Philadelphia: Elsevier/ Saunders; 2016.

8. Oo WM, Hunter DJ. Disease modification in osteoarthritis: are we there yet? Clin Exp Rheumatol. 2019;37(Suppl 120(5)):135-40.

9. Neogi T. The epidemiology and impact of pain in osteoarthritis. Osteoarthr Cartil. 2013;21(9):1145-53. https://doi.org/10.1016/j.joca.2013.03.018.
10. Malfait AM, Miller RE, Block JA: Targeting neurotrophic factors: novel approaches to musculoskeletal pain. Pharmacol Ther 2020;211:107553.

11. Malfait AM, Miller RJ. Emerging targets for the management of osteoarthritis pain. Curr Osteoporos Rep. 2016;14(6):260-8. https://doi.org/10.1007/s11914016-0326-z.

12. van den Bosch MHJ, van Lent $\mathrm{P}$, van der Kraan PM. Identifying effector molecules, cells, and cytokines of innate immunity in OA. Osteoarthr Cartil. 2020;28(5):532-43. https://doi.org/10.1016/j.joca.2020.01.016.

13. Miller RE, Tran PB, Das R, Ghoreishi-Haack N, Ren D, Miller RJ, Malfait AM. CCR2 chemokine receptor signaling mediates pain in experimental osteoarthritis. Proc Natl Acad Sci U S A. 2012;109(50):20602-7. https://doi. org/10.1073/pnas.1209294110.

14. Longobardi L, Temple JD, Tagliafierro L, Willcockson H, Esposito A, D'Onofrio N, Stein E, Li T, Myers TJ, Ozkan H, Balestrieri ML, Ulici V, Loeser RF, Spagnoli A. Role of the C-C chemokine receptor-2 in a murine model of injury-induced osteoarthritis. Osteoarthr Cartil. 2017;25(6):914-25. https://doi. org/10.1016/j.joca.2016.11.004

15. Miotla Zarebska J, Chanalaris A, Driscoll C, Burleigh A, Miller RE, Malfait AM, Stott B, Vincent TL. CCL2 and CCR2 regulate pain-related behaviour and early gene expression in post-traumatic murine osteoarthritis but contribute little to chondropathy. Osteoarthr Cartil. 2017;25(3):406-12. https://doi.org/1 0.1016/j.joca.2016.10.008.

16. Dubin AE, Patapoutian A. Nociceptors: the sensors of the pain pathway. J Clin Invest. 2010;120(11):3760-72. https://doi.org/10.1172/JCl42843.

17. Woller SA, Eddinger KA, Corr M, Yaksh TL. An overview of pathways encoding nociception. Clin Exp Rheumatol. 2017;35(Suppl 107(5)):40-6.

18. Basbaum Al, Bautista DM, Scherrer G, Julius D. Cellular and molecular mechanisms of pain. Cell. 2009;139(2):267-84. https://doi.org/10.1016/j.cell.2 009.09.028.

19. Willis WD Jr. The role of TRPV1 receptors in pain evoked by noxious thermal and chemical stimuli. Exp Brain Res. 2009;196(1):5-11. https://doi.org/10.1 007/s00221-009-1760-2.

20. Wemmie JA, Taugher RJ, Kreple CJ. Acid-sensing ion channels in pain and disease. Nat Rev Neurosci. 2013;14(7):461-71. https://doi.org/10.103 8/nrn3529.

21. Murthy SE, Loud MC, Daou I, Marshall KL, Schwaller F, Kuhnemund J, Francisco AG, Keenan WT, Dubin AE, Lewin GR et al: The mechanosensitive ion channel Piezo2 mediates sensitivity to mechanical pain in mice. Sci Transl Med. 2018;10(462):eaat9897.

22. Diogenes A, Ferraz CC, Akopian AN, Henry MA, Hargreaves KM. LPS sensitizes TRPV1 via activation of TLR4 in trigeminal sensory neurons. J Dent Res. 2011;90(6):759-64. https://doi.org/10.1177/0022034511400225.

23. Baral P, Udit S, Chiu IM. Pain and immunity: implications for host defence. Nat Rev Immunol. 2019;19(7):433-47. https://doi.org/10.1038/s41577-0190147-2.

24. Oh SB, Tran PB, Gillard SE, Hurley RW, Hammond DL, Miller RJ. Chemokines and glycoprotein 120 produce pain hypersensitivity by directly exciting primary nociceptive neurons. J Neurosci. 2001;21 (14):5027-35. https://doi. org/10.1523/JNEUROSCI.21-14-05027.2001.

25. Miller RJ, Malfait AM, Miller RE. The innate immune response as a mediator of osteoarthritis pain. Osteoarthr Cartil. 2020;28(5):562-71. https://doi.org/1 0.1016/j.joca.2019.11.006.

26. Kim YS, Chu Y, Han L, Li M, Li Z, LaVinka PC, Sun S, Tang Z, Park K, Caterina $\mathrm{MJ}$, et al. Central terminal sensitization of TRPV1 by descending serotonergic facilitation modulates chronic pain. Neuron. 2014;81(4):873-87. https://doi. org/10.1016/j.neuron.2013.12.011

27. Glasson SS, Blanchet TJ, Morris EA. The surgical destabilization of the medial meniscus (DMM) model of osteoarthritis in the 129/SvEv mouse. Osteoarthr Cartil. 2007;15(9):1061-9. https://doi.org/10.1016/j.joca.2007.03.006.

28. Miller RE, Ishihara S, Bhattachanyya B, Delaney A, Menichella DM, Miller R, Malfait AM. Chemogenetic inhibition of pain neurons in a mouse model of osteoarthritis. Arthritis Rheumatol. 2017;69(7):1429-39. https:/doi.org/10.1002/art.40118.

29. Miller RE, Kim YS, Tran PB, Ishihara S, Dong X, Miller RJ, Malfait AM. Visualization of peripheral neuron sensitization in a surgical mouse model of osteoarthritis by in vivo calcium imaging. Arthritis Rheumatol. 2018;70(1): 88-97. https://doi.org/10.1002/art.40342.

30. da Silva SI, Husson Z, Bartlett JD, Smith ES. Characterization of cutaneous and articular sensory neurons. Mol Pain. 2016;12:1744806916636387.

31. Ikeuchi M, Kolker SJ, Sluka KA. Acid-sensing ion channel 3 expression in mouse knee joint afferents and effects of carrageenan-induced arthritis. J Pain. 2009;10(3):336-42. https://doi.org/10.1016/j.jpain.2008.10.010. 
32. Chisholm Kl, Khovanov N, Lopes DM, La Russa F, McMahon SB: Large scale in vivo recording of sensory neuron activity with GCaMP6. eNeuro. 2018; 5(1):ENEURO.0417-17.2018.

33. Obeidat AM, Miller RE, Miller RJ, Malfait AM. The nociceptive innervation of the normal and osteoarthritic mouse knee. Osteoarthr Cartil. 2019;27(11): 1669-79. https://doi.org/10.1016/j.joca.2019.07.012.

34. Karanth SS, Dhital S, Springall DR, Polak JM. Reinnervation and neuropeptides in mouse skin flaps. J Auton Nerv Syst. 1990;31(2):127-34 https://doi.org/10.1016/0165-1838(90)90069-U.

35. Ramieri G, Anselmetti GC, Baracchi F, Panzica GC, Viglietti-Panzica C, Modica R, Polak JM. The innervation of human teeth and gingival epithelium as revealed by means of an antiserum for protein gene product 9.5 (PGP 9.5). Am J Anat. 1990;189(2):146-54. https://doi.org/10.1002/aja.1001890205.

36. Eitner A, Pester J, Nietzsche S, Hofmann GO, Schaible HG. The innervation of synovium of human osteoarthritic joints in comparison with normal rat and sheep synovium. Osteoarthr Cartil. 2013;21(9):1383-91. https://doi.org/10.101 6/j.joca.2013.06.018.

37. Miller RE, Ishihara S, Tran PB, Golub SB, Last K, Miller RJ, Fosang AJ, Malfait AM: An aggrecan fragment drives osteoarthritis pain through Toll-like receptor 2. JCl Insight. 2018;3(6):e95704.

38. Aso K, Shahtaheri SM, Hill R, Wilson D, McWilliams DF, Nwosu LN, Chapman $\checkmark$, Walsh DA. Contribution of nerves within osteochondral channels to osteoarthritis knee pain in humans and rats. Osteoarthr Cartil. 2020;28(9): 1245-54. https://doi.org/10.1016/j.joca.2020.05.010.

39. Scanzello CR. Chemokines and inflammation in osteoarthritis: insights from patients and animal models. J Orthop Res. 2017;35(4):735-9. https://doi. org/10.1002/jor.23471.

40. Raghu $H$, Lepus $C M$, Wang Q, Wong HH, Lingampalli N, Oliviero F, Punzi L, Giori NJ, Goodman SB, Chu CR, Sokolove JB, Robinson WH. CCL2/CCR2, but not CCL5/CCR5, mediates monocyte recruitment, inflammation and cartilage destruction in osteoarthritis. Ann Rheum Dis. 2017;76(5):914-22. https://doi.org/10.1136/annrheumdis-2016-210426.

41. Haraden CA, Huebner JL, Hsueh MF, Li YJ, Kraus VB. Synovial fluid biomarkers associated with osteoarthritis severity reflect macrophage and neutrophil related inflammation. Arthritis Res Ther. 2019;21(1):146. https:// doi.org/10.1186/s13075-019-1923-x.

42. Li L, Jiang BE. Serum and synovial fluid chemokine ligand $2 /$ monocyte chemoattractant protein 1 concentrations correlates with symptomatic severity in patients with knee osteoarthritis. Ann Clin Biochem. 2015;52(Pt 2):276-82. https://doi.org/10.1177/0004563214545117.

43. Ren G, Lutz I, Railton P, Wiley JP, McAllister J, Powell J, Krawetz RJ. Serum and synovial fluid cytokine profiling in hip osteoarthritis: distinct from knee osteoarthritis and correlated with pain. BMC Musculoskelet Disord. 2018; 19(1):39. https://doi.org/10.1186/s12891-018-1955-4

44. Watt FE, Paterson E, Freidin A, Kenny M, Judge A, Saklatvala J, Williams A, Vincent TL. Acute molecular changes in synovial fluid following human knee injury: association with early clinical outcomes. Arthritis Rheumatol. 2016;68(9):2129-40. https://doi.org/10.1002/art.39677.

45. Cuellar JM, Scuderi GJ, Cuellar VG, Golish SR, Yeomans DC. Diagnostic utility of cytokine biomarkers in the evaluation of acute knee pain. J Bone Joint Surg Am. 2009;91(10):2313-20. https://doi.org/10.2106/JBJS.H.00835.

46. Cuellar VG, Cuellar JM, Kirsch T, Strauss EJ. Correlation of synovial fluid biomarkers with cartilage pathology and associated outcomes in knee arthroscopy. Arthroscopy. 2016;32(3):475-85.

47. Appleton CT, Usmani SE, Pest MA, Pitelka V, Mort JS, Beier F. Reduction in disease progression by inhibition of transforming growth factor alpha-CCL2 signaling in experimental posttraumatic osteoarthritis. Arthritis Rheumatol. 2015;67(10):2691-701. https://doi.org/10.1002/art.39255.

48. Schaible HG. Nociceptive neurons detect cytokines in arthritis. Arthritis Res Ther. 2014;16(5):470. https://doi.org/10.1186/s13075-014-0470-8.

49. Schaible HG, von Banchet GS, Boettger MK, Brauer R, Gajda M, Richter F, Hensellek S, Brenn D, Natura G. The role of proinflammatory cytokines in the generation and maintenance of joint pain. Ann N Y Acad Sci. 2010; 1193(1):60-9. https://doi.org/10.1111/j.1749-6632.2009.05301.x

50. Mousa SA, Straub RH, Schafer M, Stein C. Beta-endorphin, Met-enkephalin and corresponding opioid receptors within synovium of patients with joint trauma, osteoarthritis and rheumatoid arthritis. Ann Rheum Dis. 2007;66(7): 871-9. https://doi.org/10.1136/ard.2006.067066.

51. Roosterman D, Goerge T, Schneider SW, Bunnett NW, Steinhoff M. Neuronal control of skin function: the skin as a neuroimmunoendocrine organ. Physiol Rev. 2006;86(4):1309-79. https://doi.org/10.1152/physrev.00026.2005.
52. Jung H, Bhangoo S, Banisadr G, Freitag C, Ren D, White FA, Miller RJ. Visualization of chemokine receptor activation in transgenic mice reveals peripheral activation of CCR2 receptors in states of neuropathic pain. J Neurosci. 2009;29(25):8051-62. https://doi.org/10.1523/JNEUROSCI. 0485-09.2009.

\section{Publisher's Note}

Springer Nature remains neutral with regard to jurisdictional claims in published maps and institutional affiliations.
Ready to submit your research? Choose BMC and benefit from:

- fast, convenient online submission

- thorough peer review by experienced researchers in your field

- rapid publication on acceptance

- support for research data, including large and complex data types

- gold Open Access which fosters wider collaboration and increased citations

- maximum visibility for your research: over $100 \mathrm{M}$ website views per year

At BMC, research is always in progress.

Learn more biomedcentral.com/submissions 